\title{
Pancreatic Exocrine Insufficiency as a Complication of Gastrointestinal Surgery and the Impact of Pancreatic Enzyme Replacement Therapy
}

\author{
Adarsh Chaudhary ${ }^{a} \quad$ J. Enrique Domínguez-Muñoz ${ }^{b}$ Peter Layer ${ }^{c}$ \\ Markus M. Lerch ${ }^{d}$ \\ a Department of Gastrointestinal Surgery, Gastrointestinal Oncology and Bariatric Surgery, Medanta, The Medicity, \\ Gurgaon, India; ${ }^{b}$ Department of Gastroenterology and Hepatology, University Hospital of Santiago de Compostela, \\ Santiago de Compostela, Spain; ' Department of Medicine, Israelitic Hospital, University of Hamburg, Hamburg, \\ Germany; ${ }^{\text {d}}$ Department of Medicine, University Medicine Greifswald, Greifswald, Germany
}

\author{
Keywords \\ Malabsorption · Maldigestion · Pancreatic resection · \\ Patient management
}

\begin{abstract}
Background: Pancreatic exocrine insufficiency (PEI) is characterized by inadequate production, insufficient secretion, and/or inactivation of pancreatic enzymes, resulting in maldigestion. The aim of this review was to analyze the prevalence and pathophysiology of PEI resulting from gastrointestinal (Gl) surgery and to examine the use of pancreatic enzyme replacement therapy (PERT) for effectively managing PEI. Summary: A targeted PubMed search was conducted for studies examining the prevalence and pathophysiology of PEl in patients following GI surgery and for studies assessing the effects of PERT in these patients. PEI is a common complication following $\mathrm{Gl}$ surgery that can lead to nutritional deficiencies, which may contribute to morbidity and mortality in patients. Timely treatment of PEI with PERT can prevent malnutrition, increase quality of life, and possibly reduce the associated mortality. Treatment of PEI should aim not only to alleviate symptoms but also to achieve significant improvements in nutritional parameters. Dose optimi-
\end{abstract}

\begin{tabular}{ll}
\hline KARGER & $\begin{array}{l}\text { (c) } 2019 \text { The Author(s) } \\
\text { Published by S. Karger AG, Basel }\end{array}$ \\
E-Mail karger@karger.com & This article is licensed under the Creative Commons Attribution- \\
www.karger.com/ddi & $\begin{array}{l}\text { NonCommercial-NoDerivatives 4.0 International License (CC BY- } \\
\text { NC-ND) (http://www.karger.com/Services/OpenAccessLicense). } \\
\text { Usage and distribution for commercial purposes as well as any dis- } \\
\text { tribution of modified material requires written permission. }\end{array}$
\end{tabular}

zation of PERT is required for effective management of PEI, in addition to regular assessment of nutritional status, appropriate patient education, and reassessment if symptoms return. Key Messages: Difficulties in detecting PEI following Gl surgery can result in undiagnosed and untreated maldigestion, leading to metabolic complications and increased morbidity. Both are preventable by early administration and monitoring for optimal doses of PERT.

(c) 2019 The Author(s)

Published by S. Karger AG, Basel

\section{Introduction}

Pancreatic exocrine insufficiency (PEI) is associated with disorders of the pancreas such as chronic pancreatitis, acute necrotizing pancreatitis, and pancreatic cancer, but can also occur as a consequence of gastrointestinal (GI) and pancreatic surgery [1]. However, in patients who have undergone GI surgery, PEI appears to be underrecognized and undertreated [2]. PEI is characterized by maldigestion, usually due to structural or functional changes to GI tissue, resulting in inadequate production, insufficient secretion, limited activation, and/or inactivation of pancreatic enzymes [1,3]. Additionally, structural 
changes to the GI tract following surgery can lead to asynchronization between the release of enzymes and passage of nutrients (pancreaticocibal asynchrony) $[1,3]$. Changes to pancreatic enzyme secretion result in the malabsorption of nutrients, with malabsorption of fats and fatsoluble vitamins usually causing the initial symptoms [4]. Typically, PEI presents as steatorrhea, abdominal pain, flatulence, and bloating [2]; however, these symptoms can vary and usually only present themselves when the amount of fat, protein, and carbohydrate ingested exceeds the digestive ability of the pancreas [5]. Additionally, patients with PEI often change their diet to reduce the intake of foods that are hard to digest and to decrease steatorrhea; as a result, symptoms of malabsorption are not consistently present [5].

The correlation between PEI, secondary to a causal disease or condition, and chronic malnutrition resulting from nutrient deficiency and fat malabsorption should be a focus for physicians due to the risk of long-term complications [6]. Malnutrition arising from PEI is associated with increased risk of infection, cardiovascular disease, sarcopenia, and osteoporosis [7-14] and can lead to increased morbidity, reduced patient quality of life (QoL), and increased mortality $[2,6,15,16]$. Since PEI-associated malnutrition also has a high patient and healthcare burden, timely treatment of patients with this condition is imperative $[2,6]$.

The diagnosis of PEI can be performed using invasive direct tests of pancreatic function, such as the secretin stimulation test, or noninvasive tests, including fecal elastase-1, fecal chymotrypsin, fecal fat, and ${ }^{13} \mathrm{C}$-mixed triglyceride breath test $\left({ }^{13} \mathrm{C}-\mathrm{MTG}-\mathrm{BT}\right)[5,17]$. Direct tests of pancreatic function have the highest accuracy for detecting pancreatic secretion, but are invasive, time-consuming, expensive, and not fully standardized $[5,17]$. While the fecal elastase- 1 test is useful in detecting PEI in certain patient populations [18], its diagnostic accuracy is limited following pancreatic surgery as PEI may occur in these patients from nonpancreatic mechanisms and not only because of reduced exocrine secretion [19]. In contrast, the fecal fat test and the ${ }^{13} \mathrm{C}-\mathrm{MTG}-\mathrm{BT}$ are useful for detecting PEI following gastric and duodenal resection as they detect levels of undigested or digested products, respectively, and not pancreatic secretions [1].

The estimated prevalence of PEI in patients after pancreatic surgery is $46-100 \%$, depending on the type of resection [20-22], and there is evidence that pancreatic secretion and fat absorption are impaired in patients after gastric surgery [23-25]. Patients undergoing GI surgery are at high risk of developing PEI; therefore, the effective man- agement of this complication and associated malnutrition needs to be a key part of postoperative patient care [26].

This review aims to outline current evidence describing the pathophysiology and prevalence of PEI resulting from GI surgery and to examine the management of patients with PEI post-surgery, specifically the use of pancreatic enzyme replacement therapy (PERT) and the potential impact this may have on health and QoL in patients with PEI.

\section{Materials and Methods}

To identify publications describing the prevalence and pathophysiology of PEI in patients having undergone GI surgery, a PubMed literature search was conducted (cutoff date July 3, 2018) using the following search terms: ([pancreatic exocrine insufficiency] OR [PEI OR EPI] AND [prevalence OR pathophysiology] AND [pancreatic surgery] OR [gastric surgery]). Articles not focused on the prevalence or pathophysiology of PEI following pancreatic or gastric surgery were excluded, as well as non-English language publications. The PubMed search yielded 335 results; of these, 19 eligible publications on the prevalence of PEI were included in the review. To identify clinical trials assessing the effects of PERT on patients having undergone GI surgery, a PubMed literature search was conducted (cutoff date July 3, 2018) using the following search terms: ([pancreatic exocrine insufficiency] OR PEI OR EPI) AND ([pancreatic surgery] OR [gastric surgery]) AND (PERT OR [pancreatic exocrine replacement therapy] OR pancreatin OR pancrelipase). Articles not focused on clinical outcomes and PERT following pancreatic or gastric surgery were excluded, as well as non-English language publications. The PubMed search yielded 98 results; of these, 9 eligible publications were included in the review. The results of the abovementioned searches form the basis of this narrative review.

\section{PEI as a Complication of GI Surgery}

\section{Pancreatic Surgery}

Pathophysiology

Anatomical changes due to pancreatic surgery often lead to the development of PEI (see examples in Fig. 1) [1]. Reduction in exocrine secretion may arise after resection of the pancreas due to the removal of pancreatic parenchyma and/or potential damage to remaining pancreatic tissue, while blockage of the pancreatic duct can result from anastomosis [2]. Postprandial pancreatic secretion is initially stimulated by a vagal reflex triggered by fundus relaxation and then by the hormone cholecystokinin released by the duodenum [1]. The duodenum also releases secretin, which stimulates the production of bicarbonate from the pancreas and increases the volume of pancreatic 


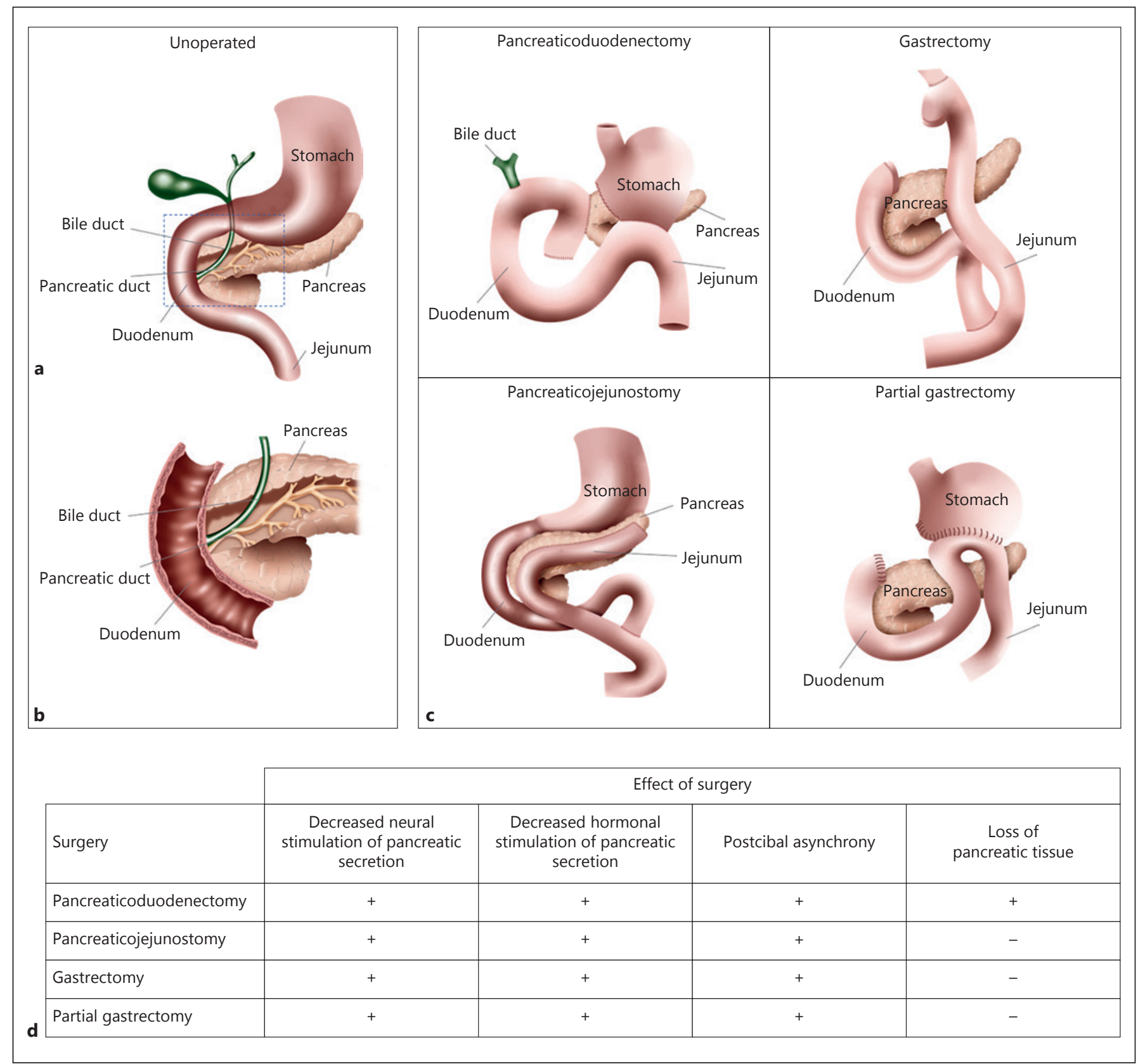

Fig. 1. Pathophysiology of common GI surgeries [1, 3, 72]. (a) Unoperated; (b) cross-section of where the pancreatic duct and the bile duct meet the duodenum; (c) anatomical changes following GI

secretions [27]. Thus, some pancreatic resection procedures may result in a loss of antro-fundic and duodenofundic reflexes as well as a loss of duodenal tissue, which may decrease pancreatic exocrine secretions and result in PEI $[1,2]$. Additionally, asynchrony between the secretion of pancreatic enzymes and bile can also result from the anatomical reconstruction caused by pancreaticoduode- surgeries; (d) possible effects of anatomical changes on pancreatic function. Plus sign indicates an effect of surgery, minus sign indicates no or minimal effect of surgery.

nectomies $[1,2]$. Such reconstructions may also contribute to malabsorption by causing the binding of bile salts to maldigested protein, carbohydrates, and fiber; these reconstructions may also predispose patients with PEI to bacterial overgrowth in the small intestine (further contributing to GI symptoms) [2]. Therefore, the type of pancreatic resection and reconstruction undertaken affects 
the risk of developing PEI post-surgery. Overall, the factors that influence the degree of PEI after surgery include: the disease for which the surgery was indicated [28]; the type and extent of resection of the pancreas, stomach, and/ or duodenum $[2,28,29]$; the quantity and quality of the remaining pancreatic tissue; the use of exocrine inhibitory medications such as octreotide; and the type of pancreatic anastomosis [2]. It should be noted that changes to gut $\mathrm{pH}$ can arise from pancreatic resection due to reduced bicarbonate secretion from the pancreas, leading to decreased activity and/or irreversible inactivation of pancreatic enzymes [28] and the precipitation of bile salts [2].

\section{Prevalence of PEI after Pancreatic Surgery}

The reported prevalence of PEI after pancreatic surgery varies widely, in part due to the type of surgical procedure [20, 21, 30-44] (Table 1), with duodenum-preserving pancreatic head resection procedures generally being associated with a lower prevalence of PEI than nonduodenum-preserving pancreaticoduodenectomy procedures $[22,45]$.

PEI prevalence rates of $75-86 \%$ have been reported after duodenum-preserving resections of the pancreatic head $[20,21,33,35]$. Distal pancreatectomies are associated with much more variable prevalence of PEI, with reported prevalence rates ranging between 19.1 and $80 \%[33,34,36,37]$. A systematic review of 94 studies with 963 patients found that, compared with distal pancreatectomy, there was a lower risk of PEI following central pancreatectomy, which had a prevalence of $11.9 \%$ [37]. By their nature, total pancreatectomy procedures always result in PEI [36].

Studies describing the development of PEI following pancreaticoduodenectomies have reported prevalence rates of between 34.7 and $100 \%$ [21,33-36, 38-44]. There is conflicting evidence regarding whether pancreaticogastrostomy or pancreaticojejunostomy after pancreaticoduodenectomy results in a higher risk of PEI, with a wide range of prevalence rates of $62.0-100 \%$ reported for pancreaticogastrostomy [38-42] and $44-100 \%$ for pancreaticojejunostomy $[39,40,43]$. A prospective, nonrandomized study $(n=34)$ that compared patients who underwent pancreaticogastrostomy $(n=14)$ or pancreaticojejunostomy $(n=20)$ found that all those in the pancreaticogastrostomy group developed severe PEI, whereas for the pancreaticojejunostomy group, 75 and $20 \%$ developed severe and mild PEI, respectively ( $p=$ 0.05 ) [39]. Even though this study was conducted in a small number of patients, the results suggest that both procedures lead to $\mathrm{PEI}$ and that a greater deterioration of exocrine function was observed following pancreatico- gastrostomy [39]. Further prospective evidence in $42 \mathrm{pa}-$ tients treated for periampullary lesions by pylorus-preserving pancreaticoduodenectomy found that $63 \%$ in the pancreaticogastrostomy group developed PEI compared with $44 \%$ in the pancreaticojejunostomy group [40]. Acid-mediated inactivation of pancreatic enzymes following pancreaticogastrostomy should be considered as a cause of PEI in these patients.

Based on the abovementioned studies, it is evident that pancreatic surgery is associated with an increased risk of PEI, with pancreaticoduodenectomies and total pancreatectomies associated with the greatest risk [36].

\section{Gastric Surgery}

Pathophysiology

Although gastric surgery does not directly involve the removal of pancreatic exocrine tissue, it leads to physiological changes that contribute to the development of PEI (see examples in Fig. 1). Like duodenal resection, gastric resection can result in the loss of antro-fundic reflexes involved in fundus relaxation, thereby disrupting neural stimulation of pancreatic secretion [1]. In addition, decreased cholecystokinin and secretin release may occur after gastric surgery due to the exclusion of the duodenum from the aboral transit of nutrients, resulting in decreased postprandial stimulation of pancreatic secretion $[1,46]$. Anatomical changes and accelerated or delayed transit of nutrients through the esophagojejunal anastomosis (in cases of esophagojejunostomy and total gastrectomy) or remaining stomach (in cases of partial gastrectomy), and/or decreased endogenous stimulation by products undergoing digestion, lead to asynchrony between gastric emptying and biliopancreatic secretion (postcibal asynchrony) $[3,28]$. This asynchrony results in the inadequate mixing of nutrients with pancreatic enzymes, causing incomplete digestion and the transit of large and hard-to-digest nutrients to the jejunal lumen [1]. The development of PEI due to gastrectomy may be further propagated by the loss of nerve supply to the pancreas due to dissection of lymph nodes in the stomach and truncal vagotomy [28]. Similar to observations in cases of pancreatic surgery, the degree and likelihood of PEI development may be determined by the type and extent of resection and/or reconstruction [2].

\section{Prevalence of PEI after Gastric Surgery}

Although there are limited clinical data regarding the prevalence of PEI after gastric surgery, 2 small trials were identified that demonstrated a link between gastric surgery and PEI (Table 2) [23, 24].
56

Dig Dis 2020;38:53-68

DOI: $10.1159 / 000501675$
Chaudhary/Domínguez-Muñoz/Layer/ Lerch 
Table 1. Estimated prevalence of PEI after pancreatic surgery

\begin{tabular}{|c|c|c|c|c|c|c|}
\hline $\begin{array}{l}\text { Type of } \\
\text { pancreatic } \\
\text { surgery }\end{array}$ & Study & Study type & Study population & $\begin{array}{l}\text { Test for } \\
\text { diagnosing PEI }\end{array}$ & Subtype of surgery $(n)$ & $\begin{array}{l}\text { PEI } \\
\text { prevalence } \\
\text { post-surgery, } \\
\%\end{array}$ \\
\hline \multirow[t]{3}{*}{$\begin{array}{l}\text { Any type of } \\
\text { pancreatic } \\
\text { surgery }\end{array}$} & {$[30]$} & $\begin{array}{l}\text { Prospective cohort } \\
\text { study with a } 6 \text {-month } \\
\text { median follow-up }\end{array}$ & $\begin{array}{l}29 \text { Patients }^{1} \text { treated } \\
\text { for cancers of the } \\
\text { pancreas, ampulla of } \\
\text { Vater or bile duct } \\
\text { ( } 52 \% \text { male, } 48 \% \\
\text { female; median age } \\
\text { of } 62 \text { years) }\end{array}$ & $\begin{array}{l}\text { FE-1 test } \\
(\leq 200 \mu \mathrm{g} / \text { stool })\end{array}$ & $\begin{array}{l}\text { Distal pancreatectomy } \\
\text { ( } 3 \text { patients) or } \\
\text { pancreaticoduodenectomy } \\
\text { ( } 26 \text { patients) }\end{array}$ & $89^{2}$ \\
\hline & {$[31]$} & $\begin{array}{l}\text { Prospective study } \\
\text { with a } 12 \text {-month } \\
\text { follow-up }\end{array}$ & $\begin{array}{l}40 \text { Patients treated for } \\
\text { pancreatic cancer } \\
\text { (55\% male, } 45 \% \\
\text { female; median age } \\
\text { of } 65 \text { years) }\end{array}$ & $\begin{array}{l}\text { CFA } \leq 93 \% ; \\
\text { FE-1 test } \\
(<200 \mu \mathrm{g} / \text { stool })\end{array}$ & $\begin{array}{l}\text { Left pancreatectomy } \\
\text { ( } 3 \text { patients), Whipple } \\
\text { (16 patients) or PPPD } \\
\text { (21 patients) }\end{array}$ & $\begin{array}{l}77 \% \text { at } 6 \\
\text { weeks; } 83 \% \\
\text { at } 12 \\
\text { months }\end{array}$ \\
\hline & [32] & $\begin{array}{l}\text { Systematic review } \\
\text { of } 19 \text { studies }\end{array}$ & $\begin{array}{l}301 \text { Patients with } \\
\text { benign tumors and } \\
163 \text { patients with } \\
\text { malignant tumors } \\
\text { who underwent } \\
\text { pancreaticoduodenectomy }\end{array}$ & $\begin{array}{l}\text { Assessment } \\
\text { methods were } \\
\text { not used as } \\
\text { inclusion/ } \\
\text { exclusion } \\
\text { criteria }\end{array}$ & $\begin{array}{l}\text { Pancreaticoduodenectomy } \\
\text { ( } 464 \text { patients) }\end{array}$ & $\begin{array}{l}25.2 \% \\
\text { benign tumor } \\
\text { group; } 49.1 \% \\
\text { malignant } \\
\text { tumor group }\end{array}$ \\
\hline \multirow[t]{6}{*}{$\begin{array}{l}\text { Comparison of } \\
\text { pancreatectomy } \\
\text { procedures }\end{array}$} & {$[21]$} & $\begin{array}{l}\text { Prospective, randomized } \\
\text { study with a }>5 \text {-year } \\
\text { median follow-up }\end{array}$ & $\begin{array}{l}85 \text { Patients treated for } \\
\text { chronic pancreatitis } \\
\text { ( } 85 \% \text { male, } 15 \% \text { female; } \\
\text { median age of } 42 \text { years) }\end{array}$ & $\begin{array}{l}\text { PEI was defined } \\
\text { as the presence } \\
\text { of steatorrhea } \\
\text { and/or the need } \\
\text { for oral pancreatic } \\
\text { enzyme } \\
\text { supplementation }^{3}\end{array}$ & $\begin{array}{l}\text { Beger or Frey } \\
\text { ( } 42 \text { patients) }\end{array}$ & 76 \\
\hline & & & & & PPPD (43 patients) & 61 \\
\hline & [33] & $\begin{array}{l}\text { Prospective study } \\
\text { with a 56-month } \\
\text { median follow-up }\end{array}$ & $\begin{array}{l}222 \text { Patients treated } \\
\text { for chronic pancreatitis } \\
\text { ( } 80 \% \text { male, } 20 \% \text { female; } \\
\text { median age of } 44 \text { years) }\end{array}$ & $\begin{array}{l}\text { Pancreatic } \\
\text { imaging (i.e., CT, } \\
\text { MRI, ERCP, and } \\
\text { endoscopic } \\
\text { ultrasound) }\end{array}$ & $\begin{array}{l}\text { Beger or Frey } \\
\text { ( } 92 \text { patients) } \\
\text { Distal pancreatectomy } \\
\text { ( } 21 \text { patients) } \\
\text { PPPD ( } 109 \text { patients) } \\
\text { Overall ( } 222 \text { patients) }\end{array}$ & $\begin{array}{l}75^{4} \\
66^{5} \\
62^{6} \\
65^{7}\end{array}$ \\
\hline & {$[34]$} & $\begin{array}{l}\text { Prospective study } \\
\text { with a } 17 \text {-month } \\
\text { median follow-up }\end{array}$ & $\begin{array}{l}110 \text { Patients treated for } \\
\text { pancreaticobiliary } \\
\text { disease ( } 55 \% \text { male, } \\
45 \% \text { female; median } \\
\text { age of } 68 \text { years) }\end{array}$ & ${ }^{13} \mathrm{C}-\mathrm{MTG}-\mathrm{BT}$ & $\begin{array}{l}\text { Distal pancreatectomy } \\
\text { ( } 30 \text { patients) } \\
\text { Pancreaticoduodenectomy } \\
\text { ( } 80 \text { patients) }\end{array}$ & $\begin{array}{l}30 \\
64\end{array}$ \\
\hline & {$[35]$} & $\begin{array}{l}\text { Long-term results } \\
\text { of a randomized } \\
\text { trial with a 7-year } \\
\text { median follow-up }\end{array}$ & $\begin{array}{l}47 \text { Patients treated for } \\
\text { chronic pancreatitis }\end{array}$ & $\begin{array}{l}\text { Fecal } \\
\text { chymotrypsin } \\
\text { test }\end{array}$ & $\begin{array}{l}\text { Frey ( } 24 \text { patients }) \\
\text { PPPD ( } 23 \text { patients) }\end{array}$ & $\begin{array}{l}86 \\
96\end{array}$ \\
\hline & {$[36]$} & $\begin{array}{l}\text { Retrospective analysis } \\
\text { of prospectively } \\
\text { collected data }\end{array}$ & $\begin{array}{l}133 \text { Patients treated } \\
\text { for pancreatic disease } \\
\text { ( } 52 \% \text { male, } 48 \% \text { female; } \\
\text { mean age of } 61 \text { years) }\end{array}$ & $\begin{array}{l}\text { FE-1 test } \\
\text { and serum } \\
\text { beta-carotene } \\
\text { test }\end{array}$ & $\begin{array}{l}\text { Distal pancreatectomy } \\
\text { (20 patients) } \\
\text { Total pancreatectomy } \\
\text { (19 patients) } \\
\text { Pancreaticoduodenectomy } \\
\text { ( } 49 \text { patients) } \\
\text { Non-resective procedures } \\
\text { ( } 45 \text { patients) }\end{array}$ & $\begin{array}{r}80 \\
100 \\
98 \\
82\end{array}$ \\
\hline
\end{tabular}


Table 1. (continued)

\begin{tabular}{|c|c|c|c|c|c|c|}
\hline $\begin{array}{l}\text { Type of } \\
\text { pancreatic } \\
\text { surgery }\end{array}$ & Study & Study type & Study population & $\begin{array}{l}\text { Test for } \\
\text { diagnosing PEI }\end{array}$ & Subtype of surgery $(n)$ & $\begin{array}{l}\text { PEI } \\
\text { prevalence } \\
\text { post-surgery, } \\
\%\end{array}$ \\
\hline \multirow[t]{9}{*}{$\begin{array}{l}\text { Pancreatectomy } \\
\text { (Beger, Frey, } \\
\text { necrosectomy) } \\
\text { procedures }\end{array}$} & {$[20]$} & $\begin{array}{l}\text { Long-term results of a } \\
\text { closed randomized } \\
\text { controlled trial with } \\
\text { a 16-year follow-up }\end{array}$ & $\begin{array}{l}45 \text { Patients (at } 16 \text {-year } \\
\text { follow-up) treated for } \\
\text { chronic pancreatitis }\end{array}$ & Not described & $\begin{array}{l}\text { Beger ( } 22 \text { patients) } \\
\text { Frey ( } 23 \text { patients) }\end{array}$ & $\begin{array}{l}77 \\
83\end{array}$ \\
\hline & {$[37]$} & $\begin{array}{l}\text { Systematic review of } \\
94 \text { studies }\end{array}$ & $\begin{array}{l}963 \text { Patients treated } \\
\text { by central or distal } \\
\text { pancreatectomy }\end{array}$ & $\begin{array}{l}\text { Assessment } \\
\text { methods were } \\
\text { not used as } \\
\text { inclusion/ } \\
\text { exclusion criteria }\end{array}$ & $\begin{array}{l}\text { Distal pancreatectomy } \\
\text { ( } 480 \text { patients) } \\
\text { Central pancreatectomy } \\
\text { ( } 359 \text { patients) }\end{array}$ & $\begin{array}{l}19.1 \\
11.9\end{array}$ \\
\hline & {$[38]$} & $\begin{array}{l}\text { Prospective study } \\
\text { with a 16-month } \\
\text { median follow-up }\end{array}$ & $\begin{array}{l}52 \text { Patients treated by } \\
\text { pancreaticogastrostomy } \\
\text { ( } 60 \% \text { male, } 40 \% \text { female; } \\
\text { mean age of } 68 \text { years) }\end{array}$ & ${ }^{13} \mathrm{C}-\mathrm{MTG}-\mathrm{BT}$ & PPPD: pancreaticogastrostomy & 65 \\
\hline & {$[39]$} & $\begin{array}{l}\text { Prospective study } \\
\text { in patients } \geq 1 \\
\text { year after surgery }\end{array}$ & $\begin{array}{l}34 \text { Patients treated with } \\
\text { PPPD who survived } \\
>1 \text { year without evidence } \\
\text { of recurrence }(56 \% \text { male, } \\
44 \% \text { female; mean age } \\
\text { of } 58 \text { years) }\end{array}$ & FE-1 test & $\begin{array}{l}\text { PPPD: pancreaticogastrostomy } \\
\text { (14 patients) } \\
\text { PPPD: pancreaticojejunostomy } \\
\text { (20 patients) }\end{array}$ & $\begin{array}{l}100 \% \text { with } \\
\text { severe PEI } \\
75 \% \text { with } \\
\text { severe PEI; } \\
20 \% \text { with } \\
\text { mild PEI }\end{array}$ \\
\hline & {$[40]$} & $\begin{array}{l}\text { Prospective study } \\
\text { with a } 37 \text { - and } 103 \text {-month } \\
\text { mean follow-up } \\
\text { for pancreaticogastrostomy } \\
\text { and pancreaticojejunostomy, } \\
\text { respectively }\end{array}$ & $\begin{array}{l}42 \text { Patients } \\
\text { treated for } \\
\text { periampullary } \\
\text { lesions ( } 50 \% \text { male, } \\
50 \% \text { female; median } \\
\text { age of } 56 \text { and } \\
67 \text { years for } \\
\text { pancreaticogastrostomy } \\
\text { and } \\
\text { pancreaticojejunostomy } \\
\text { groups, respectively) }\end{array}$ & $\begin{array}{l}\text { PEI was defined } \\
\text { as the presence } \\
\text { of steatorrhea } \\
\text { and/or the need } \\
\text { for oral pancreatic } \\
\text { enzyme } \\
\text { supplementation }{ }^{3}\end{array}$ & $\begin{array}{l}\text { PPPD: pancreaticogastrostomy } \\
\text { (19 patients) } \\
\text { PPPD: pancreaticojejunostomy } \\
\text { (23 patients) }\end{array}$ & $\begin{array}{l}63 \\
44\end{array}$ \\
\hline & {$[41]$} & $\begin{array}{l}\text { Study with a } 32 \text {-month } \\
\text { median follow-up }\end{array}$ & $\begin{array}{l}19 \text { Patients }^{8} \text { treated for } \\
\text { benign or malignant } \\
\text { pancreatic tumors } \\
\text { ( } 37 \% \text { male, } 63 \% \text { female; } \\
\text { mean age of } 55 \text { years) }\end{array}$ & $\begin{array}{l}\text { Fecal fat analysis } \\
\text { and FE test }\end{array}$ & PPPD: pancreaticogastrostomy & 100 \\
\hline & {$[42]$} & $\begin{array}{l}\text { Retrospective study } \\
\text { with a } 17 \text {-month } \\
\text { median follow-up }\end{array}$ & $\begin{array}{l}61 \text { Patients mostly } \\
\text { treated for carcinomas } \\
\text { or neoplasms ( } 61 \% \text { male, } \\
39 \% \text { female; mean age } \\
\text { of } 68 \text { years) }\end{array}$ & ${ }^{13} \mathrm{C}-\mathrm{MTG}-\mathrm{BT}$ & PPPD: pancreaticogastrostomy & 62 \\
\hline & {$[43]$} & $\begin{array}{l}\text { Cross-sectional study } \\
\text { with a } 52 \text {-month } \\
\text { median follow-up }\end{array}$ & $\begin{array}{l}26 \text { Patients treated by } \\
\text { pancreaticojejunostomy } \\
\text { ( } 38 \% \text { male, } 62 \% \text { female; } \\
\text { mean age of } 61 \text { years) }\end{array}$ & FE-1 test & PPPD: pancreaticojejunostomy & 100 \\
\hline & {$[44]$} & $\begin{array}{l}\text { Retrospective analysis } \\
\text { with a } 19.6 \text {-month } \\
\text { median follow-up }\end{array}$ & $\begin{array}{l}678 \text { Patients treated by } \\
\text { partial pancreatectomy }\end{array}$ & Not specified & $\begin{array}{l}\text { Pancreaticoduodenectomy and } \\
\text { distal pancreatectomy }\end{array}$ & 34.7 \\
\hline
\end{tabular}

\footnotetext{
${ }^{1} n=27$ completed follow-up.

$245 \%$ presurgery.

${ }^{3}$ Exocrine function was not measured using quantitative tests.

4 34\% developed de novo PEI post-surgery.

5 29\% developed de novo PEI post-surgery.

${ }^{6} 34 \%$ developed de novo PEI post-surgery.

7 33\% developed de novo PEI post-surgery.

${ }^{8}$ Exocrine function tests were carried out in 17 patients out of 19.

PEI, pancreatic exocrine insufficiency; FE-1, fecal elastase-1; CFA, coefficient of fat absorption; ERCP, endoscopic retrograde cholangiopancreatography; CT, computed tomography; MRI, magnetic resonance imaging; ${ }^{13} \mathrm{C}-\mathrm{MTG}-\mathrm{BT},{ }^{13} \mathrm{C}$-mixed triglyceride breath test; PPPD, pylorus-preserving pancreaticoduodenectomy.
} 
Table 2. Estimated prevalence of PEI after gastric surgery

\begin{tabular}{|c|c|c|c|c|c|c|}
\hline $\begin{array}{l}\text { Type of } \\
\text { gastric } \\
\text { surgery }\end{array}$ & Study & Study type & Study population & $\begin{array}{l}\text { Test for } \\
\text { diagnosing PEI }\end{array}$ & Subtype of surgery $(n)$ & $\begin{array}{l}\text { PEI } \\
\text { prevalence } \\
\text { post-surgery, } \\
\%\end{array}$ \\
\hline \multirow[t]{2}{*}{ Gastrectomy } & [23] & $\begin{array}{l}\text { Prospective } \\
\text { study with a } \\
\text { 3-month } \\
\text { follow-up }\end{array}$ & $\begin{array}{l}15 \text { Patients }^{1} \text { treated for } \\
\text { gastric cancer }(80 \% \text { male, } \\
20 \% \text { female; median age } \\
\text { of } 62 \text { years) }\end{array}$ & $\begin{array}{l}\text { Secretin-cerulein } \\
\text { test }\end{array}$ & Total gastrectomy & 100 \\
\hline & {$[24]$} & $\begin{array}{l}\text { Comparative } \\
\text { study with an } \\
\text { 18-month } \\
\text { median } \\
\text { follow-up }\end{array}$ & $\begin{array}{l}31 \text { Patients treated for } \\
\text { gastric cancer compared } \\
\text { to } 15 \text { healthy controls }(71 \% \\
\text { male, } 29 \% \text { female; mean } \\
\text { age of } 64 \text { years for treatment } \\
\text { groups) }\end{array}$ & ${ }^{13} \mathrm{C}-\mathrm{MTG}-\mathrm{BT}$ & $\begin{array}{l}\text { Roux-en-Y reconstruction } \\
\text { after subtotal gastrectomy } \\
\text { (14 patients) } \\
\text { Billroth I reconstruction } \\
\text { after subtotal gastrectomy } \\
\text { (17 patients) }\end{array}$ & 62.3 \\
\hline
\end{tabular}

${ }^{1}$ Exocrine function tests were carried out in 9 patients out of 15.

$\mathrm{PEI}$, pancreatic exocrine insufficiency; ${ }^{13} \mathrm{C}-\mathrm{MTG}-\mathrm{BT},{ }^{13} \mathrm{C}$-mixed triglyceride breath test.

A prospective study in 15 patients who had undergone total gastrectomy for gastric cancer and received an exocrine function test found that all developed severe PEI within 3 months post-surgery [23]. A comparative study of 31 patients who underwent Roux-en-Y $(n=14)$ or Billroth $\mathrm{I}(n=17)$ reconstructions after subtotal gastrectomy found that fat digestive and absorptive function was reduced following both procedures compared to 15 healthy controls [24]. The Roux-en-Y reconstruction led to a greater reduction in fat digestion and absorption, as assessed by the percentage of ${ }^{13} \mathrm{CO}_{2}$ cumulative dose at $7 \mathrm{~h}$ (\% CD-7 h), compared to the Billroth I reconstruction $(8.1[ \pm 3.4]$ vs. $11.1 \%[ \pm 3.4]$, respectively, $p=0.02$, compared with $13.9 \%$ [ \pm 7.2$]$ for controls) [24]. Based on the abovementioned data regarding the prevalence of PEI after gastric surgery, the type and extent of surgery may contribute in varying degrees to the development and prevalence of PEI.

\section{Impact of PEI after GI Surgery}

PEI following pancreatic surgery, if left untreated or undertreated, is associated with considerable morbidity related to GI symptomatology, malnutrition, and reduction in the patient's QoL and can ultimately lead to decreased long-term survival $[31,36]$. A retrospective analysis of prospectively obtained data in 133 patients undergoing pancreatic surgery for pancreatic disease concluded that the development of PEI was associated with substantially reduced patient QoL [36]. A prospective study in 40 patients undergoing pancre- atic surgery for pancreatic cancer found that those with PEI had lower QoL scores using the EORTC QLQ-C30 questionnaire (of note, the reduction in QoL was only statistically significant in the case of insomnia $[p=$ $0.001]$ ) [31]. It should be noted that the decrease in QoL in patients with PEI was not significant in this patient population (with the exception of insomnia) [31] likely due to the effects of progressing pancreatic cancer, which would further reduce QoL to a greater extent than PEI.

Post-surgery, the presence of PEI may also lead to increased pain. A prospective study in 224 patients undergoing pancreatic surgery for chronic pancreatitis found a strong association between the presence of PEI and frequent pain (at least once a week) at follow-up [33]. Further retrospective analysis of 147 patients with chronic pancreatitis undergoing pancreatic surgery demonstrated that untreated PEI at hospital discharge $(p=0.04$; $\operatorname{Exp}[\mathrm{B}]=2.102 ; 95 \%$ CI 1.04-4.26) along with postoperative insulin dependence $(p=0.03 ; \operatorname{Exp}[\mathrm{B}]=2.111$; 95\% CI 1.09-4.09) were significant risk factors for reduced long-term survival [15]. Although well-designed prospective studies are clearly needed, the abovementioned data highlight the clinical relevance of PEI in patients following pancreatic surgery, a patient group in which PEI is underrecognized and undertreated. Physicians need to be more aware of the importance of diagnosing and adequately treating this condition as soon as it arises. 


\section{Management of PEI with PERT}

PERT is considered the standard treatment for PEI [4, $7,47]$. It involves the supplementation of pancreatic lipase, amylase, and protease at doses leading to improvement of symptoms and nutritional status [47]. Modern formulations of PERT comprise enteric-coated $\mathrm{pH}$-sensitive mini-microspheres, microspheres, or micro-tablets, which prevent the degradation of enzymes in the stomach and allow their release in the duodenum at $\mathrm{pH}>5.5[4,28]$. PERT facilitates the improvement of nutritional status and weight gain in patients with PEI, by effectively correcting the cause of malabsorption [4]. A recent large retrospective observational study showed that PERT was independently associated with improved survival following pancreaticoduodenectomy for cancer [48]. In this study, the effect of PERT on improved survival was predominantly observed among patients with a dilated pancreatic duct $(\geq 3 \mathrm{~mm})$ [48]. In line with this study, undertreatment with PERT following pancreatic surgery is associated with reduced survival and QoL [15]. A prospective, cross-sectional study in 91 patients who had undergone pancreatic surgery, and who received PERT, found that $68 \%$ of these patients still suffered from steatorrhea symptoms and 39\% lost weight, suggesting that they were being undertreated [49]. Of note, the median dose of PERT was 150,000 units of lipase per day, and $25 \%$ of patients received $\leq 75,000$ units per day [49]; thus, the dose of PERT used to treat many of these patients was considerably lower than the most recent recommendations for the treatment of PEI following GI surgery $(75,000$ units with meals and 50,000 units with snacks) [5].

\section{Improvement of Malabsorption and Nutritional}

Status with PERT after GI Surgery

Although there are limited clinical trial data for PERT use in patients who have undergone GI surgery, several studies have demonstrated the efficacy of PERT in this patient population (Table 3) [50-58]. Following a 1-year open-label extension of a 1-week, double-blind, placebocontrolled, parallel-group study in 51 patients with severe PEI due to pancreatic resection, PERT led to significant improvements in the coefficient of fat absorption (CFA; $p<0.001$ ), coefficient of nitrogen absorption (CNA; $p<$ $0.001)$, body weight $(p<0.05)$, and body mass index (BMI; $p<0.05)$ [55].

The nutritional status and digestive function of 9 patients who had undergone pancreaticoduodenectomy with sclerosis of the residual pancreatic stump were as- sessed 2 years after the surgery (baseline), and subsequently after administration of PERT for 6 months in a prospective study [50]. PERT was associated with normalization of nutritional status, as assessed by serum albumin levels, total iron binding capacity, and total lymphocyte count, and a significant increase in body weight $(p<0.05)[50]$.

In cases of local resection-longitudinal pancreaticojejunostomy, improvements in fat malabsorption were shown in a small placebo-controlled trial in 11 patients who had undergone surgery for chronic pancreatitis. All patients received PERT for 4 weeks postoperatively before they were randomized to receive either PERT or placebo for a further 4 weeks [51]. An additional 4 weeks of PERT was associated with significant improvements in CFA compared with placebo $(p<0.02)$ [51]. Although nutritional status, as assessed by levels of thiamine, folate, and vitamins $\mathrm{A}, \mathrm{B} 12, \mathrm{D}$, and $\mathrm{E}$, was not significantly altered in this study, 4 patients randomized to receive PERT for a further 4 weeks had gained $>3.6 \mathrm{~kg}$ of body weight at the end of the 8-week study period [51]. Similarly, a placebo-controlled, double-blind, parallel-group study in 54 patients with PEI due to chronic pancreatitis $(n=40)$ or pancreatic surgery $(n=14)$ found that treatment with PERT for 7 days was associated with improvements in CFA $(p<0.0001)$ and CNA $(p=0.001)$ compared with placebo [53]. In a 6-month open-label extension of this study, PERT resulted in significant improvements in body weight $(p<0.0001)$, in addition to a numerical but nonsignificant increase in BMI of $0.9 \mathrm{~kg} / \mathrm{m}^{2}$, indicating improvements in nutritional status [54].

The abovementioned data suggest that PERT is associated with improvements in fat and protein malabsorption, in addition to other nutritional parameters (serum albumin levels, total iron binding capacity, and total lymphocyte count), and may be an effective treatment for potential malnutrition following GI surgery.

\section{PEI Symptom Control with PERT after Pancreatic Surgery}

The use of PERT in patients following pancreatic surgery is also effective in reducing the common GI symptoms of PEI. A 6-month hospital-based study in patients who underwent pancreaticoduodenectomy found that fecal fat excretion was reduced from 32.8 to 16.7 g per day with PERT use [50]. A randomized, double-blind, crossover study comparing PERT administered in both standard and high-dose capsules in 37 patients who underwent pancreatectomy found these PERT formulations had similar efficacy in terms of fecal fat excretion, ab-
60

Dig Dis 2020;38:53-68

DOI: $10.1159 / 000501675$
Chaudhary/Domínguez-Muñoz/Layer/ Lerch 
dominal pain, and global symptoms; however, $56 \%$ of patients still had fecal fat excretion of $>7 \mathrm{~g}$ per day, suggesting that, with a mean overall dose of 155,000 units of lipase per day, this patient population was undertreated [52]. In a 7-day placebo-controlled trial, PERT was associated with significant improvements in flatulence $(p=$ $0.006)$ and stool consistency $(p=0.03)$ [53], and with significant improvements in stool frequency $(p<0.001)$ in the 6-month open-label extension phase of this trial, designed as a parallel-group study of patients with PEI due to chronic pancreatitis or pancreatic surgery $(n=48)$ [54]. Significant reductions in stool frequency $(p<0.001)$ were reported following 1 year of PERT in 51 patients with severe PEI due to pancreatic resection [55]. Therefore, although the volume of data currently available is limited in patients following pancreatic surgery, PERT appears to be effective for the treatment of GI symptoms arising from PEI.

\section{PEI Symptom Control with PERT after Gastric Surgery}

Though PEI often arises because of gastric surgery, only a few studies have assessed the use of PERT to treat PEI in this patient population. A placebo-controlled, double-blind study in 52 patients with PEI who had undergone total gastrectomy for gastric cancer found no significant improvement in fat assimilation following administration of PERT compared with placebo [56]. Although there were no significant differences in body weight or GI symptoms between the PERT and the placebo group, PERT was associated with overall improvement in symptoms compared with placebo $(p=0.006)$ [56]. In addition, data from a small historical placebocontrolled, double-blind, crossover study in 15 patients who underwent total gastrectomy with Roux-en-Y anastomosis for stomach cancer found that administration of PERT was associated with a significant decrease in fecal fat excretion from 643 to $501 \mathrm{mmol} / 72 \mathrm{~h}(p<0.05)$ in patients with severe steatorrhea $(n=7)$; however, fecal fat excretion was not significantly decreased overall [57]. Likewise, stool consistency was significantly improved in the PERT group (score of $7.6[ \pm 0.5]$ ) compared to placebo (score of $9.3[ \pm 0.7], p<0.05$ ) [57]. A pilot study conducted in 22 patients with PEI arising after esophagectomy found that $64 \%$ of these patients had symptomatic improvement and that $41 \%$ of patients increased in weight after treatment with PERT [58]. Overall, the evidence for PERT use in patients with PEI following gastric surgery suggests that this treatment may be beneficial; however, there is a need for well-designed, large, controlled trials for PERT, using modern enzyme preparations, in this patient population. Before new data are available, the possibility of PEI and the need for PERT should be considered in patients after gastric surgery, for both symptom and nutritional control.

\section{National and International Guidelines on PERT Use after GI Surgery}

Globally, various guidelines on the management of PEI are in agreement regarding the importance of PERT in addressing PEI after GI surgery (Table 4) [45, 59-61]. Proactive screening of all patients for PEI following pancreatic surgery is recommended [61] and administration of PERT should start as soon as PEI is diagnosed, or if there is a high clinical suspicion of PEI due to the presence of GI symptoms $[45,60]$. Timely diagnosis and treatment of PEI is imperative in patients who have undergone GI surgery, since use of PERT can lead to increased QoL [45, 61], improvements in overall wellbeing [56], and reduced malnutrition-associated mortality post-surgery [60].

Spanish guidelines acknowledge that diagnosis of PEI in patients who have undergone pancreatic surgery can be difficult; therefore, the guidelines recommend the use of PERT in patients with high clinical suspicion of the condition due to their presenting symptoms, with retrospective diagnosis confirmed by improvement of symptoms, nutritional markers, and/or body weight after PERT [45]. Romanian guidelines suggest routine administration of PERT after surgery for chronic pancreatitis, even when no clinical signs of PEI are present [60]. This approach is mirrored in the Italian guidelines, in which algorithms are presented for monitoring and treating PEI following pancreatic or gastric surgery; PERT administration is recommended for patients with malignant disease (with the exception of cases of atypical resection), especially following pancreaticoduodenectomy [59]. For patients with benign disease, the assessment of PEI is suggested pre- and post-pancreaticoduodenectomy, and PERT should be administered if PEI is detected, particularly in cases in which typical resections extend beyond the right side of the portal vein [59]. There is no universal agreement on the need for routine testing for PEI in patients undergoing pancreatectomy, with the Italian guidelines suggesting that it is not necessary in patients undergoing typical or atypical pancreatectomies (except in cases where typical resections extend beyond the right side of the portal vein) [59]. Therefore, the consensus from various guidelines on the management of PEI is that the 


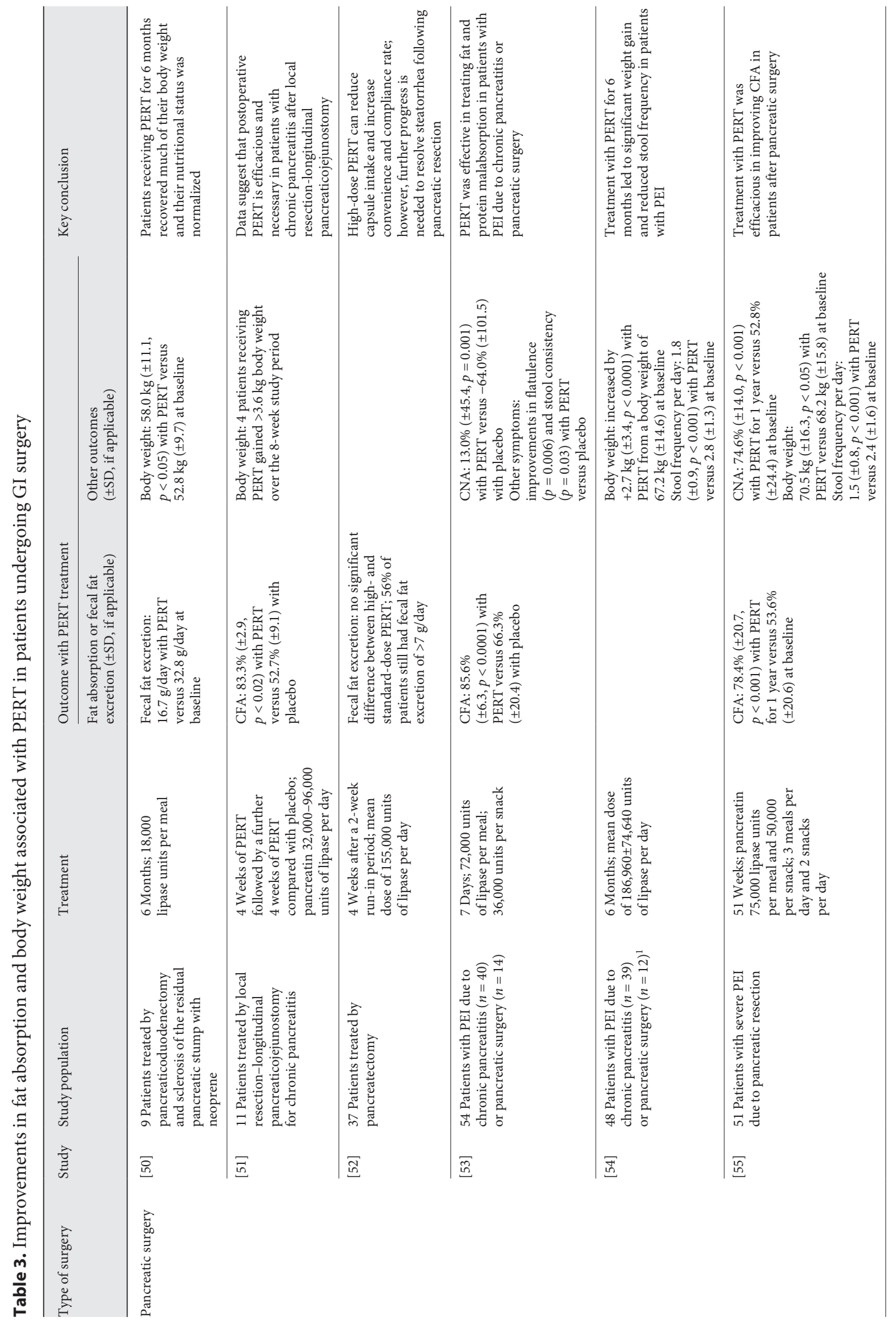




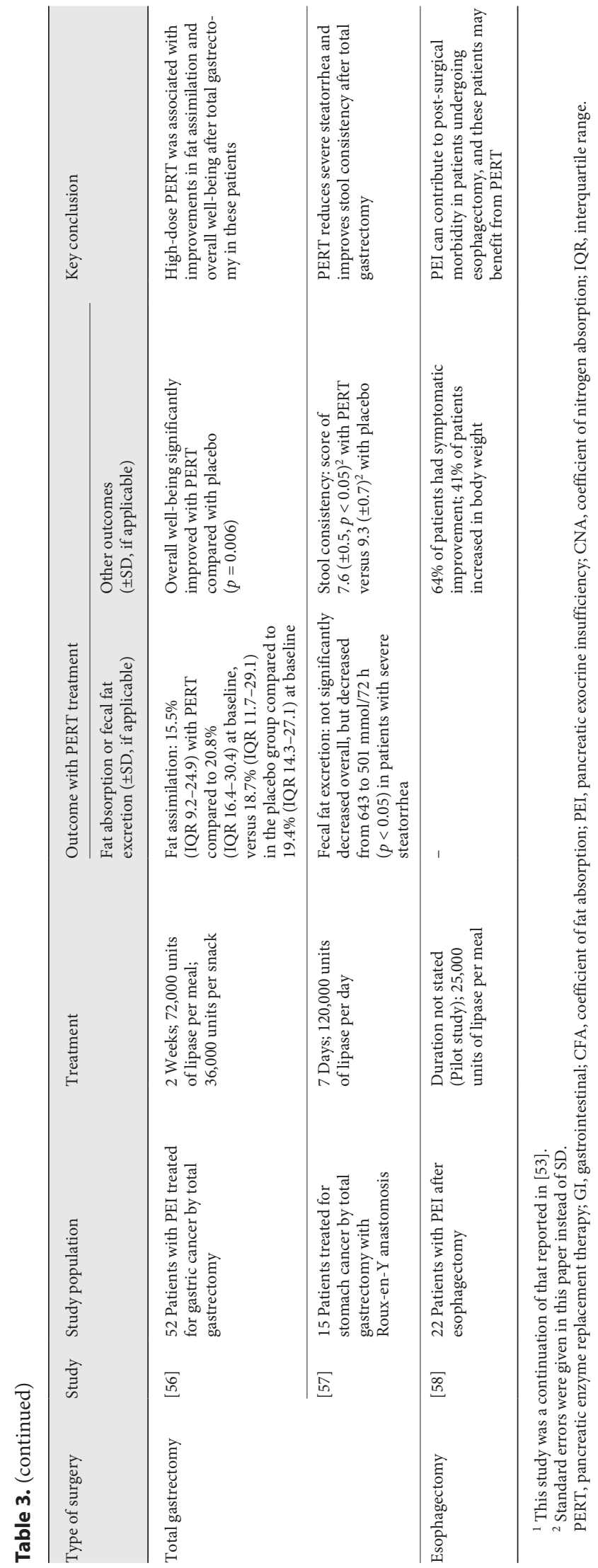

use of PERT should be routinely considered in patients after GI surgery (Table 4) [45, 59-61], particularly after resections that are associated with higher risk of PEI [59] in order to reduce mortality associated with the condition [60].

\section{Adequate PERT Dosing in Patients after GI Surgery}

Recommendations for the dosing of PERT for the management of PEI vary $[5,26,45,59,60,62]$. Guidelines suggest starting doses in adults ranging between 25,000 and 75,000 units of lipase per meal and 10,000-50,000 units per snack to treat PEI following GI surgery (Table 4) $[45,59-61]$. Studies have found that the starting doses of 75,000 units of lipase with meals and 50,000 units with snacks achieved significant increases in CFA values [53, 55]; however, these CFA values were still lower than CFA values in healthy individuals which are usually $>90 \%$ [63]. Due to the difficulties of normalizing an anatomically altered GI transit, a starting dose of 75,000 units of lipase with meals has been suggested for patients with PEI following GI surgery (Fig. 2) [5].

The dose of PERT administered should be monitored and progressively increased to the lowest effective dose until symptoms of steatorrhea are resolved $[2,4,18,26$, $59,60]$. However, nutritional deficiencies can still persist even when the PERT dose is high enough to improve symptoms of PEI [64, 65]; therefore, dosages of PERT should also be tailored to ensure normalization of the levels of nutritional markers, such as retinol-binding protein, albumin, and prealbumin [66]. Previously, maximal doses of 75,000-80,000 units of lipase per meal [26] or 10,000 units of lipase/kg of body weight/day [60] have been recommended due to the risk of fibrosing colonopathy associated with very high doses of PERT in patients with cystic fibrosis [26]. However, it has also been argued that evidence of an association between fibrosing colonopathy and high doses of PERT is very limited in patients without cystic fibrosis, and as a result, dose escalation should not be hindered in symptomatic or malnourished patients [2].

PERT administration is recommended during meals rather than before, in order for enzyme release to coincide with gastric emptying [60]. This recommendation on timing of PERT administration was based on a prospective, randomized, open-label, crossover clinical study in patients with chronic pancreatitis, which showed higher fat digestion in patients receiving PERT with meals $\left({ }^{13} \mathrm{CO}_{2}\right.$ recovery of $61.4 \% \pm 21.4)$ or just after meals $\left({ }^{13} \mathrm{CO}_{2}\right.$ recovery of $60.6 \% \pm 21.8)$ compared to those receiving PERT before meals $\left({ }^{13} \mathrm{CO}_{2}\right.$ recovery of $\left.53.9 \% \pm 20.3\right)$ [67]. 
Table 4. Guidelines on PERT use in patients with PEI following GI surgery

\begin{tabular}{|c|c|c|c|c|c|}
\hline Guideline & Study & $\begin{array}{l}\text { Method of } \\
\text { assessment }\end{array}$ & $\begin{array}{l}\text { Type of GI } \\
\text { surgery }\end{array}$ & Dosing recommendations & $\begin{array}{l}\text { Level of evidence for } \\
\text { dosing }\end{array}$ \\
\hline $\begin{array}{l}\text { Spanish Association of } \\
\text { Pancreatology (2016) }\end{array}$ & {$[45]$} & GRADE & Pancreatic & $\begin{array}{l}72,000-75,000 \text { units of lipase } \\
\text { per meal; 36,000-50,000 per snack }\end{array}$ & $\begin{array}{l}2 \mathrm{c}, \text { weak } \\
\text { recommendation } \\
\text { and low quality } \\
\text { of evidence }\end{array}$ \\
\hline $\begin{array}{l}\text { Romanian Association for } \\
\text { Pancreatic Pathology (2015) }\end{array}$ & {$[60]$} & $\begin{array}{l}\text { Oxford } \\
\text { classification }\end{array}$ & $\begin{array}{l}\text { Gastric or } \\
\text { pancreatic }\end{array}$ & $\begin{array}{l}\text { Initial dose: } 40,000 \text { units of lipase } \\
\text { per meal; } 10,000-25,000 \text { per snack }\end{array}$ & $\begin{array}{l}\text { 1b, evidence from } \\
\text { individual RCTs } \\
\text { with narrow } \\
\text { confidence interval }\end{array}$ \\
\hline $\begin{array}{l}\text { Australasian Pancreatic } \\
\text { Club (2015) }\end{array}$ & {$[61]$} & $\begin{array}{l}\text { Oxford } \\
\text { classification }^{1}\end{array}$ & $\begin{array}{l}\text { Gastric or } \\
\text { pancreatic }\end{array}$ & $\begin{array}{l}\text { Generally: }{ }^{2} 25,000-40,000 \text { units } \\
\text { of lipase per meal; } 10,000 \text { per snack }\end{array}$ & 5 , expert opinion ${ }^{3}$ \\
\hline
\end{tabular}

\footnotetext{
${ }^{1}$ With the addition of level 3c: critical review of literature.

${ }^{2}$ For gastric surgery; specific dosing recommendations were not stated for pancreatic surgery, although the dose should generally be in the region of 25,000-50,000 units of lipase.

${ }^{3}$ Without explicit critical appraisal, bench research or "first principles".

PERT, pancreatic enzyme replacement therapy; PEI, pancreatic enzyme insufficiency; GI, gastrointestinal; GRADE, Grading of Recommendations, Assessment, Development and Evaluation; NA, not applicable; RCT, randomized controlled trial.
}

Coadministration of proton pump inhibitors (PPIs) with PERT is recommended in cases where symptoms are not resolved with PERT alone [2, 26, 59, 68]; however, their use is controversial [60] due to limited evidence of their effectiveness in improving malabsorption [2], with a retrospective analysis of 34 trials $(n=1,142)$ suggesting that there is no significant difference in CFA in patients administered PERT with or without PPIs [69]. Additionally, it has been recommended that some patients may benefit from a PPI following pancreaticoduodenectomy in order to reduce ulceration at the gastrojejunostomy [2].

\section{Ongoing Patient Management after GI Surgery}

Continuous follow-up of patients treated with PERT is important to ensure optimal management of the symptoms of PEI and nutritional status $[61,70,71]$; a proposed algorithm for the management of PEI using PERT in patients who have undergone GI surgery is shown in Figure 2. Diagnostic tests used to confirm the presence of PEI, such as the ${ }^{13} \mathrm{C}-\mathrm{MTG}-\mathrm{BT}$ and the fecal fat test, can be used to monitor the response to PERT $[1,60,70]$. Nutritional evaluation of patients with PEI is necessary to ensure that malnutrition is avoided [4]; this could include evaluation of body weight and routine nutritional markers in the blood, such as fat-soluble vitamins, albumin, prealbumin, retinol-binding protein, zinc, and magnesium, among others $[45,66,70,71]$. Additionally, the sometimes complex nutritional needs of patients with PEI [4] mean that regular assessment by an experienced dietitian can be beneficial $[2,4,26,71]$. Supplementation of fat-soluble vitamins $[59,60]$ and other micronutrients, such as zinc and selenium, may be necessary if patients continue to have these micronutrient deficiencies [59].

Smaller, more frequent meals are recommended as these tend to be better tolerated $[18,26,60]$ and may allow more efficient mixing of chyme with pancreatic enzymes than 3 large meals per day [26]. Restriction of fat intake should be avoided in patients with PEI; a normal fat-containing diet (30\% of calories from fat) [60] is recommended along with administration of PERT $[2,18,26$, $59,60]$. Of note, the Italian guidelines recommend creation of a personalized diet for patients after major GI surgery to prevent weight loss and anorexia [59].

The Spanish guidelines recommend that the frequency of follow-up visits should depend on the clinical and nutritional status of patients and that further follow-up should probably be on-demand once optimal symptom and nutritional management is achieved [45]. Conversely, a UK expert opinion review recommends regular review of symptoms and dietary adequacy, and suggest that patients should be reassessed if symptoms return or worsen [2]. Importantly, patient education on PERT use is rec- 


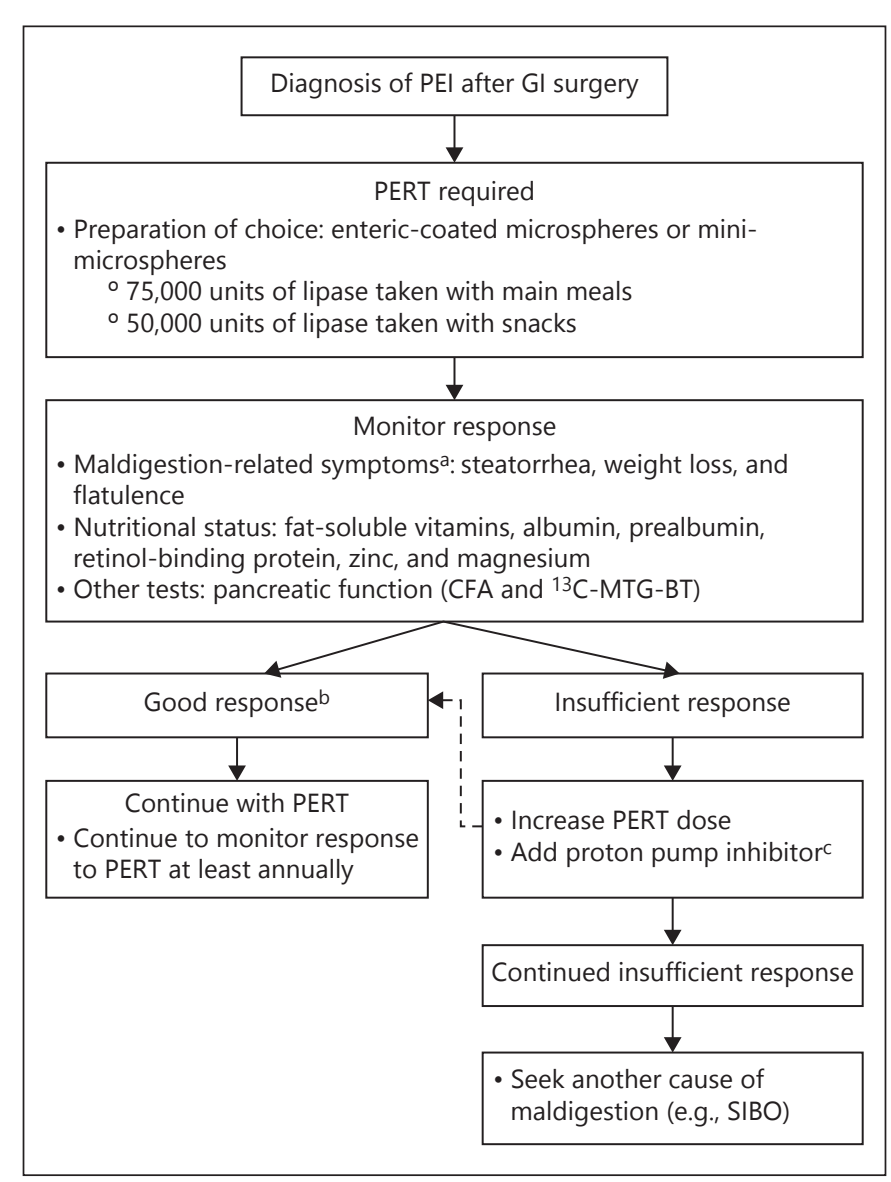

Fig. 2. Proposed algorithm for the management of PEI using PERT following GI surgery $[5,61,70,71] .{ }^{a}$ In clinical practice, the clinical and nutritional improvement of the patient is a sufficient enough criterion to evaluate response. ${ }^{b}$ Improvement in symptoms, nutritional status, and QoL and improved results of pancreatic function tests. ${ }^{\mathrm{c}}$ In case of insufficient symptom relief and/or nutritional status not normalized; PPI therapy is not indicated after total gastrectomy. PEI, pancreatic exocrine insufficiency; GI, gastrointestinal; PERT, pancreatic enzyme replacement therapy; CFA, coefficient of fat absorption; ${ }^{13} \mathrm{C}-\mathrm{MTG}-\mathrm{BT},{ }^{13} \mathrm{C}$-mixed triglyceride breath test; SIBO, small intestinal bacterial overgrowth.

ognized as key to ensuring optimal administration in all circumstances, including holidays, meals out, and hot weather [2]. Therefore, effective management of PEI requires regular monitoring of both symptoms and nutritional status to allow tailored PERT administration.

\section{Conclusion}

GI surgery can lead to removal of exocrine tissue and/ or have effects on the passage of food particles and the processes involved in promoting their digestion by pan- creatic enzymes $[1,2]$. These changes in the anatomy and functioning of the GI tract can result in PEI, a common long-term complication following pancreatic or gastric surgery $[1,2]$. PEI is associated with malnutrition and subsequent morbidities that may have detrimental effects on patient QoL and mortality [31,36]. Therefore, the timely diagnosis and treatment of PEI is vital to prevent the development of a state of malnutrition and has the potential to improve the long-term outcomes of patients who have undergone GI surgery [5]. PERT is effective in improving malabsorption, nutritional status, and BMI [50-58], thereby minimizing the effects of PEI-associated malnutrition on patient morbidity and possibly mortality [5]. Multiple guidelines on the management of PEI recommend routine screening of patients following GI surgery, particularly for procedures associated with a higher likelihood of causing PEI, such as pancreaticoduodenectomies [18, 26, 59, 60, 71]. Management of PEI should go beyond symptom control and aim to bring significant improvement in nutritional parameters, since nutritional deficiencies substantially contribute to morbidity and mortality in patients' post-surgery [5]. Therefore, effective management of PEI encompasses adequate dose escalation until optimal dosage of PERT is reached, regular assessment of the nutritional status of patients, appropriate patient education on optimal administration of PERT, and reassessment if symptoms reappear.

\section{Acknowledgment}

Editorial assistance was provided to authors during the drafting of this manuscript by Alpharmaxim Healthcare Communications.

\section{Statement of Ethics}

The authors have no ethical conflicts to disclose.

\section{Disclosure Statement}

A.C. has participated in speaking activities for Abbott Laboratories Ltd. J.E.D.-M. has participated in consulting and speaking activities for Abbott Laboratories Ltd., Mylan N.V., and Allergan plc. P.L. has participated in consulting and speaking activities for Abbott Laboratories Ltd., Allergan, Almirall, Dr. Falk Pharma $\mathrm{GmbH}$, Nordmark Arzneimittel GmbH and Co. KG, and Shire. M.M.L. has participated in consulting and speaking activities for AbbVie Ltd., Abbott Laboratories Ltd., Dr. Falk Pharma GmbH, AstraZeneca plc, Nordmark Arzneimittel GmbH and Co. KG, Centogene AG, and KMG. 


\section{Funding Sources}

Funding for editorial assistance was provided by Abbott Established Pharmaceuticals.

\section{Author Contributions}

All authors contributed to the interpretation of data and to manuscript conception, design and drafting, approved the final manuscript for submission, and agree to be accountable for all aspects of the work.

\section{References}

1 Domínguez-Muñoz JE. Pancreatic enzyme replacement therapy: exocrine pancreatic insufficiency after gastrointestinal surgery. HPB (Oxford). 2009 Dec;11(suppl 3):3-6.

2 Phillips ME. Pancreatic exocrine insufficiency following pancreatic resection. Pancreatology. 2015 Sep-Oct;15(5):449-55.

3 Mössner J, Keim V. Pancreatic enzyme therapy. Dtsch Arztebl Int. 2010 Aug;108(34-35): 578-82.

4 Imrie CW, Connett G, Hall RI, Charnley RM. Review article: enzyme supplementation in cystic fibrosis, chronic pancreatitis, pancreatic and periampullary cancer. Aliment Pharmacol Ther. 2010 Nov;32(suppl 1):1-25.

5 Dominguez-Muñoz JE. Diagnosis and treatment of pancreatic exocrine insufficiency. Curr Opin Gastroenterol. 2018 Sep;34(5): $349-54$.

6 Sikkens EC, Cahen DL, Kuipers EJ, Bruno MJ Pancreatic enzyme replacement therapy in chronic pancreatitis. Best Pract Res Clin Gastroenterol. 2010 Jun;24(3):337-47.

7 Krishnamurty DM, Rabiee A, Jagannath SB, Andersen DK. Delayed release pancrelipase for treatment of pancreatic exocrine insufficiency associated with chronic pancreatitis. Ther Clin Risk Manag. 2009 Jun;5(3):507-20.

8 Bresnahan KA, Tanumihardjo SA. Undernutrition, the acute phase response to infection, and its effects on micronutrient status indicators. Adv Nutr. 2014 Nov;5(6):702-11.

9 McCauley LA, Thomas W, Laguna TA, Regelmann WE, Moran A, Polgreen LE. Vitamin D deficiency is associated with pulmonary exacerbations in children with cystic fibrosis. Ann Am Thorac Soc. 2014 Feb;11(2):198-204.

10 Simoneau T, Bazzaz O, Sawicki GS, Gordon C; Associations with Inflammation and Bacterial Colonization. Vitamin D status in children with cystic fibrosis. Associations with inflammation and bacterial colonization. Ann Am Thorac Soc. 2014 Feb;11(2):205-10.

11 Sikkens EC, Cahen DL, Koch AD, Braat H, Poley JW, Kuipers EJ, et al. The prevalence of fat-soluble vitamin deficiencies and a decreased bone mass in patients with chronic pancreatitis. Pancreatology. 2013 May-Jun; 13(3):238-42.

12 Rhodes B, Nash EF, Tullis E, Pencharz PB, Brotherwood M, Dupuis A, et al. Prevalence of dyslipidemia in adults with cystic fibrosis. J Cyst Fibros. 2010 Jan;9(1):24-8.

13 Shintakuya R, Uemura K, Murakami Y, Kondo N, Nakagawa N, Urabe K, et al. Sarcopenia is closely associated with pancreatic exocrine insufficiency in patients with pancreatic disease. Pancreatology. 2017 Jan-Feb;17(1):705.

14 de la Iglesia D, Vallejo-Senra N, López-López A, Iglesias-Garcia J, Lariño-Noia J, NietoGarcía L, et al. Pancreatic exocrine insufficiency and cardiovascular risk in patients with chronic pancreatitis: a prospective, longitudinal cohort study. J Gastroenterol Hepatol. 2019 Jan;34(1):277-83.

15 Winny M, Paroglou V, Bektas H, Kaltenborn A, Reichert B, Zachau L, et al. Insulin dependence and pancreatic enzyme replacement therapy are independent prognostic factors for long-term survival after operation for chronic pancreatitis. Surgery. 2014 Feb; 155(2):271-9.

16 de la Iglesia-Garcia D, Vallejo-Senra N, Iglesias-Garcia J, López-López A, Nieto L, Domínguez-Muñoz JE. Increased risk of mortality associated with pancreatic exocrine insufficiency in patients with chronic pancreatitis. J Clin Gastroenterol. 2018 Sep;52(8): e63-72.

17 Laterza L, Scaldaferri F, Bruno G, Agnes A, Boškoski I, Ianiro G, et al. Pancreatic function assessment. Eur Rev Med Pharmacol Sci. 2013;17(suppl 2):65-71.

18 Hoffmeister A, Mayerle J, Beglinger C, Büchler MW, Bufler P, Dathe K, et al.; members of the guideline committee. English language version of the S3-consensus guidelines on chronic pancreatitis: Definition, aetiology, diagnostic examinations, medical, endoscopic and surgical management of chronic pancreatitis. Z Gastroenterol. 2015 Dec;53(12): 1447-95.

19 Benini L, Amodio A, Campagnola P, Agugiaro F, Cristofori C, Micciolo R, et al. Fecal elastase-1 is useful in the detection of steatorrhea in patients with pancreatic diseases but not after pancreatic resection. Pancreatology. 2013 Jan-Feb;13(1):38-42.

20 Bachmann K, Tomkoetter L, Erbes J, Hofmann B, Reeh M, Perez D, et al. Beger and Frey procedures for treatment of chronic pancreatitis: comparison of outcomes at 16-year follow-up. J Am Coll Surg. 2014 Aug;219(2): 208-16.

21 Keck T, Adam U, Makowiec F, Riediger $\mathrm{H}$, Wellner U, Tittelbach-Helmrich D, et al. Short- and long-term results of duodenum preservation versus resection for the management of chronic pancreatitis: a prospective, randomized study. Surgery. 2012 Sep;152(3 suppl 1):S95-102.

22 Bartel MJ, Asbun H, Stauffer J, Raimondo M. Pancreatic exocrine insufficiency in pancreatic cancer: a review of the literature. Dig Liver Dis. 2015 Dec;47(12):1013-20.

23 Friess H, Böhm J, Müller MW, Glasbrenner B, Riepl RL, Malfertheiner P, et al. Maldigestion after total gastrectomy is associated with pancreatic insufficiency. Am J Gastroenterol. 1996 Feb;91(2):341-7.

24 Nakamura H, Murakami Y, Morifuji M, Uemura K, Hayashidani Y, Sudo T, et al. Analysis of fat digestive and absorptive function after subtotal gastrectomy by a 13C-labeled mixed triglyceride breath test. Digestion. 2009;80(2):98-103.

25 Tataranni PA, Mingrone G, Raguso CA, De Gaetano A, Tacchino RM, Castagneto M, et al. Twenty-four-hour energy and nutrient balance in weight stable postobese patients after biliopancreatic diversion. Nutrition. 1996 Apr;12(4):239-44.

26 Toouli J, Biankin AV, Oliver MR, Pearce CB, Wilson JS, Wray NH; Australasian Pancreatic Club. Management of pancreatic exocrine insufficiency: Australasian Pancreatic Club recommendations. Med J Aust. 2010 Oct;193(8): 461-7.

27 Gullo L, Priori P, Costa PL, Mattioli G, Labò G. Action of secretin on pancreatic enzyme secretion in man. Studies on pure pancreatic juice. Gut. 1984 Aug;25(8):867-73.

28 Keller J, Layer P. Human pancreatic exocrine response to nutrients in health and disease. Gut. 2005 Jul;54(suppl 6):vi1-28.

29 Diener MK, Rahbari NN, Fischer L, Antes G, Büchler MW, Seiler CM. Duodenum-preserving pancreatic head resection versus pancreatoduodenectomy for surgical treatment of chronic pancreatitis: a systematic review and meta-analysis. Ann Surg. 2008 Jun; 247(6):950-61.

30 Sikkens EC, Cahen DL, de Wit J, Looman CW, van Eijck C, Bruno MJ. Prospective assessment of the influence of pancreatic cancer resection on exocrine pancreatic function. $\mathrm{Br}$ J Surg. 2014 Jan; 101(2):109-13.

31 Halloran CM, Cox TF, Chauhan S, Raraty MG, Sutton R, Neoptolemos JP, et al. Partial pancreatic resection for pancreatic malignancy is associated with sustained pancreatic exocrine failure and reduced quality of life: a prospective study. Pancreatology. 2011;11(6): 535-45. 
32 Beger HG, Poch B, Mayer B, Siech M. New onset of diabetes and pancreatic exocrine insufficiency after pancreaticoduodenectomy for benign and malignant tumors: a systematic review and meta-analysis of long-term results. Ann Surg. 2018 Feb;267(2):259-70.

33 Riediger H, Adam U, Fischer E, Keck T, Pfeffer F, Hopt UT, et al. Long-term outcome after resection for chronic pancreatitis in 224 patients. J Gastrointest Surg. 2007 Aug; 11(8): 949-59.

34 Yuasa Y, Murakami Y, Nakamura H, Uemura $\mathrm{K}$, Ohge H, Sudo T, et al. Histological loss of pancreatic exocrine cells correlates with pancreatic exocrine function after pancreatic surgery. Pancreas. 2012 Aug;41(6):928-33.

35 Strate T, Bachmann K, Busch P, Mann O, Schneider C, Bruhn JP, et al. Resection vs drainage in treatment of chronic pancreatitis: long-term results of a randomized trial. Gastroenterology. 2008 May;134(5):1406-11.

36 Belyaev O, Herzog T, Chromik AM, Meurer $\mathrm{K}$, Uhl W. Early and late postoperative changes in the quality of life after pancreatic surgery. Langenbecks Arch Surg. 2013 Apr;398(4): 547-55.

37 Iacono C, Verlato G, Ruzzenente A, Campagnaro T, Bacchelli C, Valdegamberi A, et al. Systematic review of central pancreatectomy and meta-analysis of central versus distal pancreatectomy. Br J Surg. 2013 Jun;100(7):87385.

38 Nakamura H, Murakami Y, Uemura $\mathrm{K}$, Hayashidani Y, Sudo T, Ohge H, et al. Reduced pancreatic parenchymal thickness indicates exocrine pancreatic insufficiency after pancreatoduodenectomy. J Surg Res. 2011 Dec;171(2):473-8.

39 Jang JY, Kim SW, Park SJ, Park YH. Comparison of the functional outcome after pylorus-preserving pancreatoduodenectomy: pancreatogastrostomy and pancreatojejunostomy. World J Surg. 2002 Mar;26(3):366-71.

40 Fang WL, Su CH, Shyr YM, Chen TH, Lee RC, Tai LC, et al. Functional and morphological changes in pancreatic remnant after pancreaticoduodenectomy. Pancreas. 2007 Nov; 35(4):361-5.

41 Lemaire E, O’Toole D, Sauvanet A, Hammel P, Belghiti J, Ruszniewski P. Functional and morphological changes in the pancreatic remnant following pancreaticoduodenectomy with pancreaticogastric anastomosis. $\mathrm{Br}$ Surg. 2000 Apr;87(4):434-8.

42 Nakamura H, Murakami Y, Uemura K, Hayashidani Y, Sudo T, Ohge H, et al. Predictive factors for exocrine pancreatic insufficiency after pancreatoduodenectomy with pancreaticogastrostomy. J Gastrointest Surg. 2009 Jul;13(7):1321-7.

43 Nordback I, Parviainen M, Piironen A, Räty S, Sand J. Obstructed pancreaticojejunostomy partly explains exocrine insufficiency after pancreatic head resection. Scand J Gastroenterol. 2007 Feb;42(2):263-70.

44 Elliott IA, Epelboym I, Winner M, Allendorf JD, Haigh PI. Population-level incidence and predictors of surgically induced diabetes and exocrine insufficiency after partial pancreatic resection. Perm J. 2017;21:16-095.

45 Sabater L, Ausania F, Bakker OJ, Boadas J, Domínguez-Muñoz JE, Falconi M, et al. Evidence-based guidelines for the management of exocrine pancreatic insufficiency after pancreatic surgery. Ann Surg. 2016 Dec;264(6): 949-58.

46 Satake K, Nishiwaki H, Umeyama K. Comparative studies of plasma secretin response after reconstructive surgery of the stomach and pancreas. Ann Surg. 1985 Apr;201(4): $447-51$.

47 Nakajima K, Oshida H, Muneyuki T, Kakei M. Pancrelipase: an evidence-based review of its use for treating pancreatic exocrine insufficiency. Core Evid. 2012;7:77-91.

48 Roberts KJ, Schrem H, Hodson J, Angelico R, Dasari BVM, Coldham CA, et al. Pancreas exocrine replacement therapy is associated with increased survival following pancreatoduodenectomy for periampullary malignancy. HPB (Oxford). 2017 Oct;19(10):859-67.

49 Sikkens EC, Cahen DL, van Eijck C, Kuipers EJ, Bruno MJ. The daily practice of pancreatic enzyme replacement therapy after pancreatic surgery: a northern European survey: enzyme replacement after surgery. J Gastrointest Surg. 2012 Aug;16(8):1487-92.

50 Braga M, Cristallo M, De Franchis R, Mangiagalli A, Zerbi A, Agape D, et al. Pancreatic enzyme replacement therapy in post-pancreatectomy patients. Int J Pancreatol. 1989;5 (suppl):37-44.

51 Van Hoozen CM, Peeke PG, Taubeneck M Frey CF, Halsted CH. Efficacy of enzyme supplementation after surgery for chronic pancreatitis. Pancreas. 1997 Mar;14(2):174-80.

52 Neoptolemos JP, Ghaneh P, Andrén-Sandberg A, Bramhall S, Patankar R, Kleibeuker $\mathrm{JH}$, et al. Treatment of pancreatic exocrine insufficiency after pancreatic resection. Results of a randomized, double-blind, placebo-controlled, crossover study of high vs standard dose pancreatin. Int J Pancreatol. 1999 Jun; 25(3):171-80

53 Whitcomb DC, Lehman GA, Vasileva G, Malecka-Panas E, Gubergrits N, Shen Y, et al. Pancrelipase delayed-release capsules (CRE$\mathrm{ON}$ ) for exocrine pancreatic insufficiency due to chronic pancreatitis or pancreatic surgery: a double-blind randomized trial. Am J Gastroenterol. 2010 Oct;105(10):2276-86.

54 Gubergrits N, Malecka-Panas E, Lehman GA, Vasileva G, Shen Y, Sander-Struckmeier S, et al. A 6-month, open-label clinical trial of pancrelipase delayed-release capsules (Creon) in patients with exocrine pancreatic insufficiency due to chronic pancreatitis or pancreatic surgery. Aliment Pharmacol Ther. 2011 May; 33(10):1152-61.

55 Seiler CM, Izbicki J, Varga-Szabó L, Czakó L, Fiók J, Sperti C, et al. Randomised clinical trial: a 1-week, double-blind, placebo-controlled study of pancreatin $25000 \mathrm{Ph}$. Eur. minimicrospheres (Creon 25000 MMS) for pancre- atic exocrine insufficiency after pancreatic surgery, with a 1-year open-label extension. Aliment Pharmacol Ther. 2013 Apr;37(7): 691-702.

56 Brägelmann R, Armbrecht U, Rosemeyer D, Schneider B, Zilly W, Stockbrügger RW. The effect of pancreatic enzyme supplementation in patients with steatorrhoea after total gastrectomy. Eur J Gastroenterol Hepatol. 1999 Mar;11(3):231-7.

57 Armbrecht U, Lundell L, Stockbrügger RW. The benefit of pancreatic enzyme substitution after total gastrectomy. Aliment Pharmacol Ther. 1988 Dec;2(6):493-500.

58 Huddy JR, Macharg FM, Lawn AM, Preston SR. Exocrine pancreatic insufficiency following esophagectomy. Dis Esophagus. 2013 Aug;26(6):594-7.

59 Pezzilli R, Andriulli A, Bassi C, Balzano G, Cantore M, Delle Fave G, et al.; Exocrine Pancreatic Insufficiency collaborative (EPIc) Group. Exocrine pancreatic insufficiency in adults: a shared position statement of the Italian Association for the Study of the Pancreas. World J Gastroenterol. 2013 Nov;19(44):7930-46.

60 Gheorghe C, Seicean A, Saftoiu A, Tantau M, Dumitru E, Jinga M, et al.; Romanian Association for Pancreatic Pathology. Romanian guidelines on the diagnosis and treatment of exocrine pancreatic insufficiency. J Gastrointestin Liver Dis. 2015 Mar;24(1):117-23.

61 Australasian Pancreatic Club: Australasian guidelines for the management of pancreatic exocrine insufficiency, October 2015.

62 Löhr JM, Oliver MR, Frulloni L. Synopsis of recent guidelines on pancreatic exocrine insufficiency. United European Gastroenterol J. 2013 Apr;1(2):79-83.

63 Borowitz D, Konstan MW, O'Rourke A, Cohen M, Hendeles L, Murray FT. Coefficients of fat and nitrogen absorption in healthy subjects and individuals with cystic fibrosis. J Pediatr Pharmacol Ther. 2007 Jan;12(1):47-52.

64 Domínguez-Muñoz JE, Iglesias-García J, Vilariño-Insua M, Iglesias-Rey M. 13C-mixed triglyceride breath test to assess oral enzyme substitution therapy in patients with chronic pancreatitis. Clin Gastroenterol Hepatol. 2007 Apr;5(4):484-8.

65 Domínguez-Muñoz JE, Iglesias-García J. Oral pancreatic enzyme substitution therapy in chronic pancreatitis: is clinical response an appropriate marker for evaluation of therapeutic efficacy? JOP. 2010 Mar;11(2):158-62.

66 Lindkvist B, Phillips ME, Domínguez-Muñoz JE. Clinical, anthropometric and laboratory nutritional markers of pancreatic exocrine insufficiency: prevalence and diagnostic use Pancreatology. 2015 Nov-Dec;15(6):589-97.

67 Domínguez-Muñoz JE, Iglesias-García J, Iglesias-Rey M, Figueiras A, Vilariño-Insua M. Effect of the administration schedule on the therapeutic efficacy of oral pancreatic enzyme supplements in patients with exocrine pancreatic insufficiency: a randomized, threeway crossover study. Aliment Pharmacol Ther. 2005 Apr;21(8):993-1000. 
68 Domínguez-Muñoz JE, Iglesias-García J, Iglesias-Rey M, Vilariño-Insua M. Optimising the therapy of exocrine pancreatic insufficiency by the association of a proton pump inhibitor to enteric coated pancreatic extracts. Gut. 2006 Jul;55(7):1056-7.

69 Sander-Struckmeier S, Beckmann K, Janssenvan Solingen G, Pollack P. Retrospective analysis to investigate the effect of concomitant use of gastric acid-suppressing drugs on the effica- cy and safety of pancrelipase/pancreatin (CRE$\left.\mathrm{ON}^{\circledR}\right)$ in patients with pancreatic exocrine insufficiency. Pancreas. 2013 Aug;42(6):983-9.

70 Löhr JM, Dominguez-Munoz E, Rosendahl J, Besselink M, Mayerle J, Lerch MM, et al.; HaPanEU/UEG Working Group. United European Gastroenterology evidence-based guidelines for the diagnosis and therapy of chronic pancreatitis (HaPanEU). United European Gastroenterol J. 2017 Mar;5(2):153-99.
71 Nikfarjam M, Wilson JS, Smith RC; Australasian Pancreatic Club Pancreatic Enzyme Replacement Therapy Guidelines Working Group. Diagnosis and management of pancreatic exocrine insufficiency. Med J Aust. 2017 Aug;207(4):161-5.

72 Kahl S, Malfertheiner P. Exocrine and endocrine pancreatic insufficiency after pancreatic surgery. Best Pract Res Clin Gastroenterol. 2004 Oct;18(5):947-55. 